NBER WORKING PAPER SERIES

REGULATION AND SUPERVISION:

AN ETHICAL PERSPECTIVE

Edward J. Kane

Working Paper 13895

http://www.nber.org/papers/w13895

\author{
NATIONAL BUREAU OF ECONOMIC RESEARCH \\ 1050 Massachusetts Avenue \\ Cambridge, MA 02138 \\ March 2008
}

The views expressed herein are those of the author(s) and do not necessarily reflect the views of the National Bureau of Economic Research.

NBER working papers are circulated for discussion and comment purposes. They have not been peerreviewed or been subject to the review by the NBER Board of Directors that accompanies official NBER publications.

(C) 2008 by Edward J. Kane. All rights reserved. Short sections of text, not to exceed two paragraphs, may be quoted without explicit permission provided that full credit, including $\odot$ notice, is given to the source. 
Regulation and Supervision: An Ethical Perspective

Edward J. Kane

NBER Working Paper No. 13895

March 2008

JEL No. G28

\begin{abstract}
$\underline{\text { ABSTRACT }}$
This essay shows that government credit-allocation schemes generate incentive conflicts that undermine the quality of bank supervision and eventually produce banking crisis. For political reasons, most countries establish a regulatory culture that embraces three economically contradictory elements: politically directed subsidies to selected bank borrowers; subsidized provision of explicit or implicit repayment guarantees for the creditors of banks that participate in the credit-allocation scheme; and defective government monitoring and control of the subsidies to leveraged risk-taking that the other two elements produce. In 2007-2008, technological change and regulatory competition simultaneously encouraged incentive-conflicted supervisors to outsource much of their due discipline to credit-rating firms and encouraged banks to securitize their loans in ways that pushed credit risks on poorly underwritten loans into corners of the universe where supervisors and credit-ratings firms would not see them.
\end{abstract}

Edward J. Kane

Department of Finance

Boston College

Chestnut Hill, MA 02467

and NBER

edward.kane@bc.edu 
Conference on Principles v. Rules in Financial Regulation University of Cambridge Judge Business School

April 11, 2008

\section{REGULATION AND SUPERVISION: AN ETHICAL PERSPECTIVE*}

\section{Edward J. Kane \\ Boston College}

Love and Marriage, love and marriage, Go together like a horse and carriage.

This I tell ya, brother, Ya can't have one without the other. Jimmy Van Heusen, Our Town (TV, 1955)

Although the yoke between "love and marriage" is markedly more flexible than it was in 1955, regulation and supervision remain tightly conjoined. Regulation focuses on rules; supervision looks to their enforcement. Etymologically, regulation is a grammatical extension of regula: the Latin word for "rules." In every country, governments make rules that define formally what a bank is, what different kinds of things banking organizations may and may not do, how and where bankers may and may not do permissible things, and what reciprocal rights and duties bankers and regulators owe to one another. Moreover, for compelling historical, cultural, economic, and political reasons, these definitions vary across countries—often greatly (Barth, Caprio, and Levine, 2006).

Differences in rules and enforcement support what has become a worldwide market for regulatory services. Just as bank managers might explore the market for any other support service that they plan to outsource, they sort through alternative regulatory schemes to ascertain the particular jurisdiction that offers them the best mix of costs and benefits for the various pieces of their product lines. In the absence of switching costs, each bank would design a series of substitute asset, liability, and hedging instruments and negotiate with (i.e., "lobby") would-be suppliers so that each deal they write could be booked in the most favorable jurisdiction.

To sort out cross-country and cross-product differences in the quality and offering prices of different regulatory entities, this paper develops the concept of an incentive- 
conflicted regulatory culture. In each country, the broad outline of this culture is determined by inherited ethical norms for individual, industry, and government behavior. However, the institutional details that constitute a particular regulatory scheme and go on to shape its particular policy instruments and their operative costs and benefits are developed cooperatively in response to the push and pull of lobbying pressures. The conflict between a top regulator's duties and outside political forces incorporates into every real-world system of bank regulation contradictory controls and subsidies that, when left unchallenged through time, tempt client banks to expose themselves to a growing chance of economic insolvency.

Many countries have experienced a banking crisis in recent years (Caprio and Klingebiel, 1996; Honohan and Klingebiel, 2003). Of these crises, a high proportion was triggered by losses generated by government efforts to allocate bank credit to wellconnected firms in politically influential sectors. The upside of these crises is that, in exposing inefficient, contradictory, and antiegalitarian elements of regulatory policies in particular countries, they generate pressure for effective reform.

\section{$\underline{\text { I. Ethics of Supervision }}$}

Economic theory presumes that, subject to external constraints, individuals choose a series of behaviors that maximize through time a personal objective function. Rules come into existence in situations where people fear that gaps in other individuals' ethical standards might allow them to behave in ways that would jeopardize the goals of a rule-making community to which they belong.

To constrain the choices that targeted parties make, rules must be backed up by supervision. Supervision entails surveillance and enforcement. Regulated parties ("regulatees") must be supervised when — and to the extent that - their objective functions tempt them to make themselves better off by disobeying either the spirit or the letter of particular rules.

A bank's incentive to circumvent or violate a given rule increases with the weight of the burdens that full compliance threatens to impose on its efforts to create value and manage risk. Dutiful enforcement revises bank incentives by rewarding compliance, punishing evasion, and searching out and closing loopholes that regulatees might use to skirt the rules. 
Rulemakers spell out the behaviors that they wish either to avoid or to promote in capital letters and usually in language almost anyone can understand. However, most rules contain a set of loopholes that is communicated either in very small print or in coded language that only the lobbyists that sponsored them can immediately see or understand. To quantify the economic burden of any rule, one must study not only the costs and benefits of compliance, but the opportunity costs of circumvention as well.

Loopholes sustain gaps in supervisory enforcement that generate a second set of rules. These secondary rules are designed to discourage appeals to higher authority and are at least partially conjectural. For example, although the formal speed limit on a given highway might be posted at (say) 55 miles per hour, drivers confidently expect the limit that police actually enforce to be higher than the posted one and to adapt predictably to exceptional circumstances (such as personal emergencies) as these unfold.

Common law and the Commonsense School of ethical theory maintain that, across any contract in which one party delegates authority to one or more others, agents and principals owe one another duties of loyalty, competence, and care. On this hypothesis, supervisors owe four key duties to the community that employs them:

1. A duty of vision: They should continually adapt their surveillance systems to counter regulatee efforts to disguise their rulebreaking;

2. A duty of prompt corrective action: They should stand ready to discipline rulebreakers whenever a violation is observed;

3. A duty of efficient operation: They should produce their services at minimum cost;

4. A duty of conscientious representation: They should be prepared to put the interest of the community they serve ahead of their own.

In principle, supervisors committed to the fourth duty would bond themselves to disclose enough information about their decisionmaking to allow the community to make them accountable for neglecting or abusing these responsibilities. In practice, institutional arrangements do not hold supervisors strongly accountable for the distributional effects of how they resolve incentive conflicts. To the contrary and in country after country, politicians require bank lending to favor designated sectors of the economy. To obtain a 
quid pro quo, bank stakeholders expect these loans to be supervised with a lighter hand, especially in times of banking turmoil (Kane, 1989).

Traditionally, supervisory duties have been exercised locally and-in a narrow and formal sense_-schemes for regulating and supervising banks are still shaped and administered on a nation-by-nation basis. Changes in rules and duties respond to the interplay of economic events with changing governmental goals and with the waxing and waning of industry pressure to relax burdensome rules or to control disruptive behaviors. Kane $(1977,1981$, and 1988) describes a dialectical process in which regulation-induced innovation engenders regulatory adjustments and regulatory adjustments (termed reregulation) engender new sources of regulatee avoidance.

Today, national schemes and resulting regulatee burdens are increasingly being influenced by competition from foreign regulatory systems. In world markets, movements of financial capital and changing asset values overlay onto the domestic policy scene a series of unfamiliar political, economic, and reputational pressures that individual-country regulatory decisionmakers must take into account. Arguably, these pressures have persuaded authorities in financial-center countries to acquiesce in loophole-ridden agreements for coordinating cross-country supervision (Basel I and II).

This paper introduces the concept of a regulation-induced financial crisis and uses it to explain how offshore regulatory competition can either reinforce or attenuate inefficient or antiegalitarian elements of incentive-conflicted banking regulation in individual countries. Regulatory competition does this mainly by inducing increases and decreases in the banking business a country's banks can capture. With technological change intensifying the influence of offshore regulators, mis-steps promise to come to a boil sooner, but may still have severe and long-lasting effects on ordinary taxpayers. This chapter exemplifies the process by analyzing how regulatory competition simultaneously encouraged incentive-conflicted supervisors to outsource much of their due discipline to credit-rating firms and encouraged banks to securitize their loans in ways that pushed credit risks into corners of the universe where supervisors and creditratings firms could not see them.

II. The Market for Regulatory Services and Its Imperfections 
Although a large literature treats banking regulation as if it were simply a tax on bank income, bankers understand that banking regulation is better conceived as a backoffice financial service that, for participants in banking markets, generates benefits as well as costs. Its benefits lie in three realms: improving customer confidence, improving customer convenience, and supporting or resisting bank efforts to accumulate and exercise market power. Because banking regulation requires resources to produce, authorities can both produce it more or less efficiently and finance it more or less fairly. Whether or not the costs of producing regulation are minimized, political activity determines its level and allocates its production costs across society. Any firm or individual implicitly pays an endogenously determined price for regulatory services. This price corresponds to the difference between the benefits that firm or household receives from bank regulation and the costs that banking regulation imposes on it. We conceive of this variable as a given taxpayer's "net regulatory benefit (or burden) from banking regulation," or NRB.

Parties that feel a stake in banking regulation routinely join together into political coalitions and lobby collectively for improvements in their NRBs. In principle, each sector's lobbyists compete self-interestedly with lobbyists from other sectors to generate regulatory benefits for their members and to shift the costs of financing their production toward parties located in other sectors.

In a world in which banking markets are globalized, services that provide regulatory benefits are available from foreign as well as domestic suppliers. Hence, the struggle by citizens and firms of any one country to maximize net benefits spills across its borders into what has become a worldwide market for financial regulation.

The market for regulatory services comprises a body of persons that carry on extensive transactions in the specific activity of promulgating, enforcing, and accepting regulatory restrictions. Regulation is supplied competitively and accepted voluntarily to the extent that entry and exit opportunities exist for banks willing to incur the transaction costs of switching all or part of their regulatory business to another supplier. Hence, although a regulator's clientele is fixed in the very short run, the jurisdictions in which a regulatee operates are voluntary over longer periods. Geographic overlaps in the global market for financial regulatory services have expanded as entry and exit costs for foreign 
financial institutions have declined around the world. Ongoing downward trends in costs of entering and exiting offshore financial markets render the margin of regulatory competition — even in developing countries_-increasingly global.

Rules and enforcement systems are continually tested and reshaped by changes in the net regulatory benefits that other jurisdictions offer. Nevertheless, jurisdictional competition for most financial products is inherently imperfect. An incumbent regulator may be said to have market power in any line in which it can lower the NRB it offers clients without completely surrendering its clientele to another regulator. Alternatively, we might say that the leaders of a regulatory agency have market power whenever the various labor, capital, and political markets from which they draw economic resources cannot hold them (and the elected politicians that appoint and sustain them) accountable for policy decisions that simultaneously lower net regulatory burdens for their clientele of lenders and borrowers and increase them for other important economic sectors.

The vigor of regulatory competition is enhanced by technological change and diminished by information asymmetries, leadership turnover, and various sources of principal-agent conflict that are inherent in governmental decisionmaking. The essence of a government's social contract is that taxpayers - as principals - award financial resources and coercive powers to governmental agents. Taxpayers hope that government officials will exercise the assigned powers to promote the "common good." However, the common good cannot be observationally defined. Moreover, especially in the short run, an agency's conception of the common good may be distorted by sectoral pressures.

Regulators routinely adopt reporting systems that make it difficult for citizens to gather information either about subsidiary goals that policymakers might be pursuing or about sectoral, bureaucratic, or personal benefits that regulatory activity might generate. Even when evidence of discriminatory or inefficient performance surfaces, it is difficult for outside observers to sort out its root causes or to correct the incentive defects responsible for it.

The value of regulatory competition lies in supplying indirect economic checks on the even-handedness and efficiency of net regulatory burdens. On the demand side, competition encourages parties that feel overburdened by their government's system of regulation to reconfigure their business to slide it into the jurisdiction of a more- 
advantageous supplier of regulatory services. It does not matter whether the new supplier is domestic agency or a foreign one. What matters is that the regulators gain some relief, the new regulator gains budgetary resources, and the old regulator loses them. The lower the transition costs of moving to a less burdensome regulatory supplier, the more complete the demand-side check becomes.

On the supply side, entry and exit costs confer competitive advantages on incumbent regulators. In competing with would-be private regulatory enterprises, government entities are advantaged by the financial strength imparted to them by the presumption that they can assign catastrophic losses to taxpayers and by their ready access to the coercive power of the state. To a nontraditional supplier, the costs of actively gearing up to oversee even a narrow category of banking deals can be substantial. The existence of these costs means that the number of potential new entrants that can economically supply regulatory services to banks in a given country is relatively limited in the short run.

Successful entry requires more than a capacity for exercising disciplinary power. To displace a seasoned regulator, would-be entrants need specific skills, a source of moral authority, and substantial financial and reputational capital. Entrants must be able to promise credibly that they can fairly and efficiently produce regulatory services and are committed and able to sustain this promise for a long while. They must be able to manipulate system of rewards and punishments that is strong enough to change the behavior of potential regulatees. The entry of newly chartered private regulators into regulatory arenas is discouraged by the costs of accumulating sufficient public standing and moral authority to be trusted with this kind of coercive authority.

In brief, the inherited market structure for regulatory services is distorted by market power that the law freely gives to government enterprises and by reputational advantages enjoyed by incumbent private regulators. On the one hand, representative democracy confers renewable monopoly power on elected politicians and the regulatory leaders they appoint. Because policymaking authority may be canceled by voters or limited ex post by the courts, this authority becomes all the stronger, the more confidently incumbent politicians may count on holding power and the more that top bureaucrats may 
count on holding onto their offices and avoiding vigorous prosecution or public censure for questionable acts.

Even in the private sector, market power is conferred in lasting fashion on a successful regulatory enterprise. It is interesting that such traditionally hard-to-dislodge incumbent regulators as a country's major stock and commodities exchanges are being subjected today to pressures from cross-country partners that hope to take over their franchise. It is unfortunate that, for key regulatory bureaus, central banks, and ministries of finance, takeover discipline cannot be so direct.

III. The Role of Incentive Conflicts and Regulatory Subsidies in Banking Fragility

Banking environments and patterns of banking regulation vary greatly from country to country. Financial-institution supervision combines a capacity to observe fluctuations in balance-sheet values ("vision") with a capacity to influence managerial actions ("control") and an incentive system that governs the pursuit and exercise of these capacities. Even when portfolios and attendant risks are concentrated within a single country, it is difficult to establish a combination of adequate oversight of institutional balance sheets, adequate authority to intervene in timely fashion, and bureaucratic incentives to detect and resolve insolvent institutions in ways that adequately protect taxpayer interests. As a result, individual countries solve this contracting problem in different ways. Although many commonalities of interest exist, systems for setting and enforcing financial rules are infested with incentive conflict. Even within a country, conflicts exist between and among:

1. Regulators and the firms they regulate;

2. Particular regulators and other societal watchdogs;

3. Regulators and the politicians to whom they must report;

4. Taxpayers and the politicians and regulators they put in office.

How a country approaches and resolves these conflicts is in part hard-wired into its political and institutional structure. For example, while many EU countries supervise banks separately from other financial institutions, some do not. A few European countries (Austria, Denmark, Germany, Sweden, the Netherlands, and the United Kingdom, in particular) have established agencies that supervise bank and nonbank 
financial institutions in an integrated way; others have to some degree integrated the oversight of at least their bank and securities sectors (Schüler, 2003).

Every country relies on its ethical norms, government regulators, and other professional watchdogs to bridge gaps in the bonding, deterrent rights (deterrency), and transparency inherent in its private contracting environment. Over time, the interaction of private and government watchdogs generates a regulatory culture. A culture may be defined as customs, ideas, and attitudes that members of a group share and transmit from generation to generation by systems of subtle and unsubtle rewards and punishments. A regulatory culture constrains the ways in which an uncooperative or even unscrupulous individual bank can be monitored and disciplined. It comprises a matrix of attitudes and beliefs about how regulators should act. These slowly changing attitudes and beliefs often express a distrust of government power that traces back to abuses observed in a possibly distant past when the country was occupied, colonized, or run by a one-party government. The culture's taboos and traditions define standards for the fair use of government power. Behind these standards are higher-order social norms that underlie a nation's political and legal environments.

The character of a country's Regulatory Culture is spanned by six specific components:

- Legal authority and reporting obligations

- Formulation and promulgation of specific rules

- Technology of monitoring for violations \& compliance

- Allowable penalties for material violations

- Duties of consultation: To guarantee fairness, regulated parties enjoy a right to procedural due process that specifies burdens of proof that regulators must meet before they can penalize violators.

- Regulatee rights to judicial review: To bond the fairness guarantee, penalized parties have access to inside and outside appeals procedures.

In large part, the details of each component are shaped by:

a. Recognition and response lags generated by the interaction of weakness in the transparency of the nation's accounting system with bureaucratic incentives and statutory and bureaucratic checks and balances; 
b. Regulatory competition brought about by the entry of foreign or differently regulated institutions;

c. Regulatory personnel's exposure to influence activity from a disciplineresistant firm's political clout, consultation rights, and appeal privileges;

d. Social norms that protect fraudsters and bumblers against prompt regulatory discipline.

Lobbying activity seeks to reshape the particular norms that officials stress and to constrain the tradeoffs they make. Within limits set by a country's regulatory culture, how particular policy strategies officials adopt actually work is determined by regulatees' ability to delay or stymie decisive intervention and to find and exploit circumventive loopholes. Some of these loopholes involve the ability to relocate loss exposures that are more closely supervised either by the home country (or by a particular host) to venues that monitor or discipline risk-taking less effectively.

The regulatory cultures of almost every country in the world today embrace in one form or another three strategic elements:

1. Politically-Directed Subsidies to Selected Bank Borrowers: The policy framework either explicitly requires_or implicitly rewards_-banks for making credit available to selected classes of borrowers at a subsidized interest rate;

2. Subsidies to Bank Risk-Taking: The policy framework commits government officials to providing on subsidized terms explicit or implicit conjectural guarantees of repayment to depositors and other bank creditors;

3. Defective Monitoring and Control of the Subsidies: The contracting and accounting frameworks used by banks and government officials fail to make anyone directly accountable for reporting or controlling the size of either subsidy in a conscientious or timely fashion.

Taken together, the first two elements in the strategy tempt banks to extract wealth surreptitiously from taxpayers and constrain loan officers to pass some of the benefits to politically favored borrowers [such as builders and would-be homeowners (especially low-income households) in the US]. Favored borrowers tend to be blocs of 
voters regularly courted by candidates for political office and financial supporters or cronies of influential government officials.

The third piece of the framework minimizes regulators' exposure to blame when things go wrong. It makes it impossible for outsiders to hold supervisors culpable for violating their ethical duties. It prevents outsiders from readily monitoring the true costs and risks generated by the first two strategies and interferes with efforts to subject the intersectoral flow of net regulatory benefits to informed debate. This gap exists because accounting systems do not report the value of regulatory benefits as a separate item for banks that receive them. In modern accounting systems, the capitalized value of regulatory subsidies is treated instead as an intangible source of value that, if booked at all, is not differentiated from other elements of a bank's so-called "franchise value." Of course, some of the subsidy is offset by tangible losses that politically influenced loans eventually force onto bank balance sheets and income statements. In principle, a tangible reserve for expected losses ought to be set up as part of the process of making a poorly underwritten or deliberately underpriced loan. Not reserving for losses imbedded in a loan's preferential terms may be conceived as planting a time bomb in the asset and networth values shown on conventional bank balance sheets. Over time, the cumulative damage from politically favored loans becomes harder and harder to hide. Between one crisis and the next, the amount of government-favored loans grows larger and larger in bank portfolios. Eventually, a shortfall of contractual cash flows makes it harder to gain financing for pools of mispriced and poorly structured loans. This is how poorly documented mortgage-backed securitizations came acropper in the US and Europe during the summer of 2007. Although officials resist the idea, creating an enforceable obligation for regulators to estimate in transparent and reproducible ways the ebb and flow of the dual subsidies would empower external watchdog organizations in the private sector to force authorities to explain whether and how these subsidies benefit taxpayers.

Sooner or later, savvy large-denomination creditors come to appreciate the unreported hole that overvalued loans imbed in the opportunity-cost value of their bank's enterprise-contributed net worth $\left(\mathrm{NW}_{\mathrm{E}}\right)$. By $\mathrm{NW}_{\mathrm{E}}$, we mean the value that an informed buyer would pay for the bank if safety-net guarantees did not exist. If a bank's $\mathrm{NW}_{\mathrm{E}}$ declines through zero, it becomes a "zombie" institution. A zombie is an insolvent 
institution that stays active only because the black magic of government guarantees leaves its creditors with no reason to force it into a corporate grave. A zombie's ability to renew its deposit funding and other debt depends entirely on the continuing credibility of the explicit and implicit government guarantees that safety-net managers attach to its obligations.

Accounting loopholes allow a zombie institution to show positive accounting net worth long after its $\mathrm{NW}_{\mathrm{E}}$ has turned negative. For example, although we now know that in June 2007 the British mortgage lender Northern Rock PLC was well on its way to becoming a zombie, management was able to post an accounting net worth equal to roughly two percent of its assets.

Systemwide fragility F increases with the number of zombies or near-zombies (Z) and with the aggregate size of the losses thought to be imbedded in their economic balance sheets:

$$
F=F\left[Z, \sum_{j=1}^{Z} N W_{E}(j)\right] .
$$

Funding problems begin not when a bank becomes a zombie, but when suppliers of largedenomination funds begin to doubt whether officials can or will continue to support its existence. Funding problems for a region's or country's banking system are intensified when doubts arise about arrangements for making taxpayers absorb the cost of guaranteeing the area's potential zombie institutions. The triggering condition is that the upper bound on the uncertain value of implicit and explicit government guarantees $\mathrm{G}$ rises so high that taxpayer resistance threatens to make it hard for authorities to raise the funds needed to pay the bill promptly or in full. Massive withdrawals by sophisticated creditors are sometimes described as "silent runs," because servicing the demands that a troubled bank receives from large creditors generates far less publicity than the queue of panicked small depositors that impatiently mills about in a conventional run.

However, silent runs greatly weaken bank balance sheets. The deposit outflows that troubled banks experience must be financed by selling liquid assets and issuing costly debt. A troubled bank's first line of defense against a silent run is to arrange loans from government institutions or from relatively well-informed banks with which it has correspondent relationships. Private rescuers usually insist on receiving appropriately 
high interest rates and demand collateralization and an upside potential for their claims. In deciding to help a correspondent bank to weather a silent run, foreign banks are apt first to lobby the IMF, the host government, and even their own government for assurances that they will not be stuck with the bill for whatever losses the rescue effort might incur.

Until officials increase the transparency and credibility of their credit support, silent runs on weak institutions tend to escalate. Troubled banks' sales of good assets and increasing funding costs reduce future income and make the fragility of their condition apparent to more and more outside observers. When a troubled bank collateralizes its good assets at or above their market value, its unbooked losses on poorly performing loans become a larger proportion of the assets that remain unpledged. The more funding a troubled bank obtains at high credit spreads, the more severely its future accounting and economic profits are squeezed and the more likely it is to engage in go-for-broke lending and funding activities that severely pressure the profit margins of healthy competitors.

A silent run puts pressure on regulators because it progressively undermines the willingness of taxpayers and stronger banks to tolerate the regulatory status quo. As a silent run unfolds, reduced profit margins spread zombieness and disturbing information is revealed about the size of taxpayers' potential involvement. At the same time, net regulatory benefits for weak and strong banks diverge more and more widely. Weak banks receive safety-net subsidies from central-bank loans and government guarantees that stronger banks and general taxpayers eventually have to pay for.

The longer a silent run proceeds, the more deeply supervisory efforts to retard the exit or to delay the formal recapitalization of inefficient and insolvent deposit institutions push the net regulatory benefits of other economic sectors into negative territory. The economic and political forces exerted when a large bank suffers open and silent runs are nicely illustrated by the British government's response to the Northern Rock debacle. In September 2007, an open depositor run on this bank was stopped by the government's promise to provide emergency funding to the $£ 114$ billion institution and to "guarantee all existing deposit arrangements." However, a silent run persisted. By yearend, emergency loans from the Bank of England reached about $£ 25$ billion and Treasury guarantees had been extended to cover most of the bank's nondeposit obligations as well. 
Well-publicized efforts to persuade stockholders and outside acquirers to inject private capital into the bank showed little progress. Finally, in February 2008, the bank was "temporarily" nationalized.

\section{Three Exculpatory Norms of Modern Crisis Management}

A severely overleveraged banking system may be portrayed as an accident waiting to happen. A regulation-induced crisis occurs when misfortune impacts a banking system whose managers have made their institutions vulnerable to this amount and type of bad luck. Figure One breaks the evolution of a regulation-induced banking crisis into five stages. The 2007-08 breakdown of arrangements for financing for structured securitizations in the US and Europe, and banking crises that rolled through Latin America, Japan, Korea, the Philippines, Malaysia, Indonesia, Thailand, and Russia during 1997-1998 passed through the first three and one-half stages of this model of crisis generation and response.

In 2007-2008, German, British, and American authorities showed again that politicians are reluctant to move beyond the stopgap partial recapitalization stage (stage 4A). As long as the hopelessness of an institution's situation can be covered up, outsiders cannot easily distinguish a wave of financial-institution insolvencies from a transitory shortage of aggregate liquidity. In either circumstance, a group of economically significant firms find it exceedingly difficult to roll over their liabilities on profitable terms. It is an accepted first-response practice for central bankers and other regulators to provide liquidity to distressed institutions as a way to buy time for their supervisory staff to investigate the extent to which irreparable insolvencies might underlie the distress. This time-buying strategy is supported by three exculpatory norms whose ethical force intensifies in times of political, market, or institutional turmoil: a mercy norm; a nationalistic norm; and a nonescalation norm.

The mercy norm holds that it is bad policy and unacceptably cruel behavior for regulators to abandon the employees, creditors, and stockholders of institutions they oversee before they can convincingly establish whether the distress is too fundamental to be remedied by subsidized loans. This norm gives regulators the discretion (if not the duty) to alleviate the initial pains of any client institution that experiences a silent run. 
The nationalistic norm presupposes that regulators should help domestic institutions and marketmakers to cope with foreign competition. In practice, this norm is reinforced by community resistance to foreign control of national credit decisions and by lobbying pressure from politically favored sectors who suspect that foreign banks will not serve their interests very well.

The nonescalation norm allows authorities to lend on subsidized terms to distressed institutions as long as they can popularize the view that doing anything else would invite a national or global financial disaster. In invoking this norm, officials must spread fear. They must argue that, without a large injection of subsidized funds, markets will set prices for troubled assets that are unreasonably low and prices for emergency credit to institutions that hold these assets that are unreasonably high and that these price movements would sweep strong and healthy institutions into the turmoil.

It is dangerous for government officials both to make these exaggerated claims and to deny the increasingly transparent flow of subsidies that partial recapitalization entails. For high-ranking regulators to keep churning out safety-net subsidies, two further conditions must hold. First, they must be able to control the flow of information, so as to keep taxpayers and the press from convincingly assessing either the magnitude of the implicit capital transfer or the antiegalitarian character of the subsidization scheme. Second, the self-interest of top regulators must be continually nourished by praise and other forms of tribute from the bankers, borrowers, and investors whose losses are being shifted to other parties.

Authorities are reluctant to move to full recapitalization until overwhelming losses reveal themselves in the form of strongly resurging crisis pressures. The longer the game goes on, the greater the risk that the reputations of incoming policymakers and the particular politicians that appoint them will be saddled unfairly with the sins of their predecessors. Although it is unwise to draw inferences from a sample of two, the U.S. savings-and-loan mess and the most recent Argentine crisis cast some light on how costs are allocated during the final stages in the life cycle of a regulation-induced crisis.

Formally, continuations and breakdowns in the burden-shifting process may be analyzed as two states of an evolutionary process. Though small on any given day, the probability (p) of a breakdown during an incentive-conflicted regulator's term in office 
increases with the fragility of the system for making good on implicit and explicit safetynet guarantees. It is convenient to represent the value of these guarantees as $\mathrm{G}$ and the cumulative size of the taxpayer's hidden responsibility for supporting the liabilities of troubled institutions as (T). T and $\mathrm{G}$ increase with system fragility (F). In turn, whenever F grows, $p$ also rises. During the early stages of an incipient crisis, increments in the probability of breakdown depend on the informativeness (A) of the accounting principles that banks and safety-net officials use to report losses and loss exposures:

$$
\mathrm{p}=\mathrm{p}[\mathrm{G}, \mathrm{T}, \mathrm{F} ; \mathrm{A}] \text {. }
$$

During these early stages, banks and their regulators are tempted to seek and provide "accounting relief." However, once market participants begin to recognize partial recapitalizations and coverups as half-measures, weaknesses in A compound the problem and improvements in A become a critical part of the crisis-resolution process. 


\section{Figure One}

\section{Five Stages of a Regulation-Induced Banking Crisis}

1. Rent-Seeking Generates Aggressive Loss Exposures at Highly Leveraged Institutions

- Pursuit of Safety-Net Subsidies Tied to Government-Promoted Forms of Lending

- Pursuit of Subsidies Tied to Other Kinds of Leveraged RiskTaking

2. Adverse Events and Industry Problems Upset Financial Markets - Banks and Regulators Keep Losses from Registering on Bank Books by Accounting Trickery and Coverup

- Large-Denomination Creditors Test the Strength of the Safety Net

- Fragility of System Rises as Good Assets are Collateralized and Endgame Incentives Induce Go-For-Broke Gambling

- Threat of Shortages in Safety-Net Funding Rises Over Time

3. Supplementation of Traditional Safety-Net Support Mechanisms

- Loans from Central-Bank Discount Window Can't Carry the Load

- Inventive Accounting Loopholes and Forms of Public Credit Expand

4. Recapitalization of Troubled Banks and Safety-Net Institutions

A. Stopgap Partial Recapitalizations: Half-Measures Move the Financial Sector Back into Stage Two of the Cycle

B. Transformation of Bank Losses into Explicit Taxpayer Obligations or Explicit Nationalization of Zombie Banks

5. Final Clean-Up of the Mess

- Reprivatization of Zombie Institutions

- Blame Heaped on Designated Scapegoats

- Credible Safety-Net Reforms are Adopted 
Rolling and incompletely resolved crises sound at least three alarms. First, the frequency and geographic extent of banking crises convincingly demonstrate that, around the world, numerous banks have found it reasonable to book potentially ruinous risks. Looking at the period 1977-1995, Caprio and Klingebiel (1996) cite 58 countries in which the net worth of the banking system was almost or entirely eliminated. Second, in country after country, domestic (and sometimes foreign) taxpayers have been billed to bail out banks, depositors, and deposit-insurance funds. Honohan and Klingebiel (2003) confirm that, in recent crises, taxpayers' bill for making good on implicit and explicit guarantees typically ran between 1 and 10 percent of GDP. The size of these bailouts establishes that, at least in crisis countries, banks managed to put large bets on the table and were able to shift a substantial amount of the downside of these bets to taxpayers. In many cases, authorities were eventually blamed for the size of the bills taxpayers were asked to pay. Officials were seen to have shirked their duties to expose and stop loss-causing patterns of credit allocation and to have compounded the damage from credit losses by not addressing individual-bank insolvencies until their situation had deteriorated disastrously.

In times of financial turmoil, weaknesses in ethical controls on the job performance of government regulators responsible for protecting the safety and soundness of financial institutions encourage regulatory forbearance. The high cost of modern crises indicates how far the risk-taking preferences of officials responsible for managing taxpayer risk exposures diverge from those of large-denomination creditors in private financial markets. Although institutional mechanisms for financing safety-net loans and guarantees differ across countries, poor information flows and incentive conflict in government policymaking complicate the treatment of banking crises everywhere.

Special problems of accountability and incentive conflict arise in managing crosscountry risk exposures. Financial regulators subject foreign banks and the foreign operations of domestic banks to patterns of regulation that differ in two important ways from those that apply to strictly domestic banking operations. First, most developed countries are willing to allow their domestic banks to book a wider range of risks in foreign subsidiaries than they are prepared to tolerate in home-country offices. This is because relationships with internationally active customers are a geographically footloose 
part of the banking business and because government officials don't expect to confront responsibility for foreign banking losses in domestic political arenas. This creates incentives for offshore banks to "overlend" into foreign markets. Second, though greatly weakened by technological change and outside political pressure, obstacle to the entry of foreign financial firms in most banking markets still exist.

\section{Globalization and Securitization of Bank Funding Opportunities}

Contemporary theories of industrial organization seek to explain how a product's market structure evolves through time to permit efficient firms and efficient contracting instruments to reshape or displace relatively less-efficient alternatives. The force of these theories is particularly easy to grasp when we focus on hypothetical markets that meet a set of ideal conditions that Baumol, Panzar, and Willig (1986) call "perfect contestability."

A market is perfectly contestable when entry and exit costs are each zero and incumbent firms exit quickly whenever they find themselves faced with negative profits. In perfectly contestable markets, low-cost firms readily displace high-cost firms and incumbent competitors are prevented from setting monopoly prices by the threat of hitand-run entry by other equally-efficient firms. Financial markets are never perfectly contestable. New entrants must adapt and expand their information systems before they can safely expand their customer base. Incumbents cannot easily abandon the pipeline of loan commitments they have promised to customers and the regulatory foundations on which inherently nontransparent financial markets must be built are burdened with inescapable entry and exit costs.

During the last thirty years, particularly in wholesale banking markets, technological change has steadily lowered entry costs for foreign and nontraditional competitors. Most of these firms undertook banking activities in innovative ways, making creative use of substitute products, substitute organizational forms, and substitute offshore locations. In some countries, the viability of a new entrant's business plan was temporarily enhanced by longstanding restrictions on how banks could compete domestically. 
Chief among the innovative methods of doing business was structured securitization. With help from investment banks, credit-rating agencies, mortgage insurers, and hedge funds, banks sliced and securitized titles to the cash flows from their loans in ways that assigned the slicing (or "tranching"), reslicing, and servicing of flows of interest and principal to separately capitalized conduit vehicles. By placing important tranches of their loans through and with foreign and nonbank firms, banks permanently layered the institutional character and broadened the geographic span of bank funding arrangements.

Innovative funding technologies benefited borrowers by integrating bank loan pricing within and across countries. However, outsourcing the funding side of a bank's balance sheet weakened its staff members' due diligence by severing the link between the income a lender could make from originating securitizable loans and the quality of its system for underwriting the loans it originated. Investors in a securitized pool of loans did not rely on either the lender's or their own due diligence. Instead, they expected credit-rating agencies to assess the risks in the positions they were offered and they expected investment banks and mortgage insurers to make sure that the returns offered would respond appropriately to differences in loan quality. Unfortunately, the naïveté with which these expectations were held undermined agents' incentives to meet them. Compensation for rating and pricing individual securities was collected as soon as the securities were floated, with little exposure to ex post blowback for personnel that might later be shown to have made a serious rating or pricing mistake. With supervisors closing their eyes to the erosion of this chain of agents' contractual incentives to execute faithfully their duties of loyalty, competence, and care, investors presumed that they were purchasing titles to well-rated and well-priced securities.

Securitization also brought firms that were supervised in different regulatory cultures and jurisdictions into sharper competition with one another. This mutual invasion of traditional markets by institutions headquartered in different regulatory cultures put pressure on particular regulatory enterprises (especially at enterprises whose leaders' remaining terms in office promised to be short) to relax vigilance as a way of defending their bureaucratic turf. In retrospect, it is clear that banking supervisors did this by regularizing and legitimating cutting-edge ways to hide or transfer risk without fully 
exploring the threats that these complex new contracting structures imposed on individual country safety nets.

Whenever a regulator acquiesced in innovative entry by a foreign or nontraditional firm, it had to relax restraints that might make it hard for its traditional clients to compete with the new entrants. Institutions pressed politicians to make this happen sooner rather than later.

Authorities' positive response to this competitive pressure has been labeled financial deregulation, but our ethical perspective makes it clear that the response is better described as desupervision.. In most countries, regulatory competition and defects in accountability led banking supervisors to assess the risks of innovative instruments of risk transfer with less watchfulness than these instruments deserved. With respect to structured securitizations, banking supervisors and mortgage-insurance firms outsourced their duty of vision to accountants and credit-rating agencies without adequately bonding the obligations they were asking them to perform. They did this despite these firms' obvious conflicts in goals and outsized delays in downgrading distressed securities in past downturns (Portes, 2008).

The contestability of banking markets is greatly reduced by the political clout that domestic banks enjoy and by the ability of supervisory entities to bill government safety nets for the losses their heedlessness might engender. In crises, safety-net subsidies disadvantage less-subsidized competitors and unreasonably sustain the operations of decapitalized banks. The contestable-markets portrayal of market-structure evolution helps us to understand that in most countries deregulation focused on unblocking entry without addressing supervisory incentives to resist the exit of important domestic banks. Bank and supervisory exit resistance attenuates the benefits to society that entry relaxation would otherwise produce. Banking crises teach foreign and nontraditional competitors the need to estimate the extent of supervisor-supported exit resistance. By standing ready to absorb the losses of unprofitable clients, a regulator (especially a central bank) can prevent low-cost entrants from earning the profits needed to justify hitand-run entry.

\section{Dialectics of a Regulation-Induced Banking Crisis}


For any policymaker, a crisis may be described as a time of upheaval that generates strong pressure for decisive changes in policy strategy. Figure Two portrays a regulation-induced banking crisis as an evolutionary process that is driven in Hegelian fashion by dialectical collisions of irreconcilable market and regulatory adjustments.

For any regulated institution, change - not rest - represents the path of profitmaking equilibrium. The Hegelian model of regulation assumes that the conflict between regulated parties and their regulators can never be completely eliminated. The contradictory forces at work in each round of adjustments are labeled the "thesis" and the "antithesis." Every sequence of adjustment and response produces a temporary "synthesis" that serves in turn as the "thesis" for a new round of action and response.

In the US, policies designed to promote homeownership encouraged borrowers and lenders alike to operate with a "perilously high degree of leverage" (Shadow Financial Regulatory Committee, 2008). For borrowers, the value of the subsidies that they could derive both from tax deductions for mortgage interest and from federal programs supporting mortgage credit increased with the amount they borrowed. For lenders, federal programs supported the securitization of home mortgages by offering cheap guarantees and by making it possible for banks to avoid capital requirements on mortgages that they chose to securitize. Bank supervisors did not require banks either to estimate or to hold capital against the implicit obligations that structured securitization vehicles passed through to a sponsor's net worth. The high degree of leverage on borrower positions meant that, if and when housing prices declined by more than a few percent, marginal borrowers would be unable to service their obligations. Once a sharp increase in delinquencies and foreclosures by subprime borrowers occurred, savvy investors revalued and cut back their positions in securitized mortgage pools. When this revaluation wiped out the equity of mortgage securitization conduits, reputational concerns persuaded bank sponsors to move a good portion of conduit losses back onto their balance sheets. Besides being billed for conduit losses, banks that had been heavily involved in originating mortgages for sale to conduits were stuck with losses on pipelines of ongoing mortgage commitments that they could no longer profitably securitize. Inevitably, silent runs on these banks tested the ability of safety-net managers to manage a spreading crisis. 
FIGURE TWO

DIALECTICS OF A REGULATION-INDUCED CRISIS

THESIS: UNSUSTAINABLE POLICY MIX

- Expansionary Monetary Policy and Loss-Causing Credit-Allocation Scheme ("politically sabotaged loans") vs. Adverse Effects of Desupervising Risks on the Costs of Providing Safety-Net Support for Loss-Making Banks

ANTITHESIS: SKEPTICAL INVESTORS AND DEPOSITORS TEST GOVERNMENTS' ABILITY TO MANAGE THE EXPANDING COSTS OF NATIONAL SAFETY NETS

- In a Banking Crisis, Market Tests consist of Silent Runs (Symptomized by a Generalized Flight to Quality and Simplicity)

- The probability of a deepening crisis rises the longer authorities refuse to contain the damage and continue to help zombie institutions to stay in play

SYNTHESIS: REFORM OCCURS WHEN AUTHORITIES CAN NO

LONGER QUELL MARKET DOUBTS ABOUT THEIR ABILITY TO

SUSTAIN THE CONTRADICTORY POLICY MIX.

- Credit-allocation scheme unravels

- Costs of sustaining decapitalized institutions become manifest 
The appropriate policy response to crisis pressures depends on the nature of the policy contradictions that occasioned the crisis. A perennial issue is to assess the potential insolvency of troubled banks and to determine how rapidly bank net worth is being undermined by falling prices on crisis-creating loans. Asset-price meltdowns are most likely to occur when incentives for overlending by domestic and offshore institutions confront a host-country policy regime that offers incentives for overborrowing at domestic households and firms. In such cases, pressure on asset prices is apt to generate a crisis-intensifying run from claims issued by the insolvent borrowers and lenders.

It is superficial to conceive of the silent runs that triggered the US securitization crisis as manifestations of an underprovision of aggregate "liquidity." In fact, the central bank has for many years accommodated overspending in the favored sector and also financed a long run of current-account deficits. A central bank can prolong a payments deficit by letting its currency decline and by drawing down the country's foreignexchange reserves and foreign lines of credit. In any consumption-driven currency devaluation, the need to rebuild the central banks' currency reserves may or may not be urgent. If it is, authorities can shrink the current-account deficit in two complementary ways: (1) by allowing the exchange rate to decline even further and (2) by tightening their mix of fiscal and monetary policies.

But when a money-center country is experiencing a banking crisis, this prescription is unattractive. These policies would impose a sizeable opportunity loss on foreign and domestic holders of the country's financial assets. The currency-adjustment half of this strategy would put inflationary pressure on domestic prices. To pile on the tight-money half of the prescription would induce a decline in aggregate economic demand, whose effects would reduce the real value of a country's financial assets in general and the net worth of its banking system in particular. This would further undermine asset values by raising prospective rates of default and delinquency on troubled assets. In crisis circumstances, it is politically impossible for authorities to ignore the effects that these adjustments would have on safety-net loss exposures.

In a financial center country, authorities face a Three-Way Policy Dilemma about how to control a silent run: 
1. Choice One: Try to finance the runs with minimal adjustment in the losscausing parts of the policy mix. We may describe this strategy as disinformational "hardball." Authorities may temporarily nationalize one or more insolvent institutions and deny that any other zombies exist. They may or may not soften the potential decline in their exchange rate by drawing down reserves or borrowing from private and official foreign sources.

2. Choice Two: Rebalance the policy mix to make it more sustainable, but only with respect to a narrowly defined window of time (e.g., until after the next election). Authorities may resolve or strengthen some of the weakest institutions and may slow monetary growth. We have described this as a strategy of "partial recapitalization."

3. Choice Three (unlikely to be chosen unless prior efforts to use one or both of the other strategies have failed dramatically): Face up to and eliminate the most obvious contradictions in the policy mix. The new policy regime should aim for a full cleanup of insolvent institutions and to establish a more incentive-compatible supervisory system going forward.

Leaving bank and corporate insolvencies unresolved fosters further malinvestment and enhances the likelihood that a deeper crisis will emerge down the line. Still, it is dangerous to acknowledge and resolve corporate and banking insolvencies in the midst of a national recession. In crisis circumstances, politicians are strongly tempted to reflate demand and to strengthen the credibility of safety-net guarantees, without doing much to resolve the incentive distortions that widespread insolvency creates.

\section{The Role of Regulatory Competition in Banking Crises}

Contradictory policies misallocate capital in the household, financial, corporate, and government-planning sectors. The result is that asset values and bank net worth eventually have to be written down. Had asset values either been supported by a sustainable expansion in productive capacity or been written down promptly as unfavorable information surfaced, silent runs would not have become large enough to test the safety nets of financial-center countries. 
The seeds of the 2007-2008 subprime crisis were sown over many decades. They did not flower into a crisis until doubts began to surface about authorities' willingness and ability to measure and absorb the losses and loss exposures confronting a suddenly decapitalized banking system. Measurement is important. As in the 1980s savings-andloan mess, crisis costs were intensified by openly delaying loss recognition at lossmaking institutions.

What the press describes as a "banking crisis" may be more accurately described as the surfacing of tensions caused by the continuing efforts of loss-making banks to force the rest of society to accept responsibility for their unpaid bills for making bad loans. In US mortgage markets, longstanding systems for subsidizing poorly underwritten loans to builders and overleveraged households imposed unbooked losses both on banks and on supporting national safety nets.

Around the world, financial institutions and markets are supported by regulatory systems that show numerous country-specific features (Wilson, 1986; Dermine, 2003; Barth, et al., 2006). Differences in patterns of financial regulation address differences that exist in the various economic, political, and bureaucratic deficiencies and inefficiencies that each country's regulatory system is overtly or covertly expected to correct (Garcia and Nieto, 2006; Herring and Schuermann, 2006).

However, the survival of differences in regulatory patterns is limited by the tendency of funding and loan-making opportunities to flow to markets and institutions that offer their customers the best deal. The extent to which net regulatory burdens on financial markets and institutions differ across countries is narrowed by the regulatory arbitrage that interjurisdictional deal flows entail. When and as technological change in information processing and telecommunications lowers the cost of transacting with foreign entities, adverse flows of capital and financial dealmaking help to persuade a nation's authorities to lower the net burdens that their regulatory framework imposes on the savers and investors that book deals in its financial markets.

In recent years, rolling banking and currency crises have become frequent for three reasons. First, advances in information and communications technology have simultaneously globalized banking markets and markets for government guarantees. Second, the globalization of markets for banking and guarantee services has made it less 
costly for domestic corporations and wealthy investors to mount silent runs on a country's zombie banks. Third, lenders, securitizers, credit-rating organizations, and supervisory authorities are not compensated in ways that make them accountable for the slow-developing but inevitable losses that their policies engender.

In 1997-1998, crises in Korea, Indonesia, Malaysia, the Philippines, and Thailand were hastened by the technologically driven absorption of these countries into an international market for loanable funds that allowed large depositors to protect themselves against the burdens of inefficient or discriminatory patterns of national regulation. Globalization put the costs and benefits of banking regulation in these countries into closer competition with the regulatory systems of offshore financial centers.

Offshore banking competition shortened in two ways the crisis-gestation period featured in traditional crisis models (such as Krugman, 1979). First, even limited entry by outside banks expanded the stock of well-priced domestically available substitutes for deposits that local citizens had previously held in host-country banks. This lowered the cost to Asian depositors of participating in a silent run on domestic banks. Second, the relative safety of foreign-bank deposit substitutes demonstrated the greater reliability of the performance guarantees written for each offshore entrant by the regulatory systems of its homeland.

Each crisis constitutes an exit cost that society incurs to shrink the domain of a high-cost or discriminatory regulator. Regulation-induced crises are triggered by efforts to avoid the inefficiencies and inequities that political maneuvering interjects into particular markets for regulatory services. Squeezing the equilibrium rents that shortsighted or corruptible officials can extract and distribute to their supporters disciplines incumbent regulators, but only at the margin. To improve public-service contracting in the longer run will require authorities to expose themselves to blowback for the delayed effects of policy mistakes by accepting a performance-based scheme of deferred compensation.

Exploitive regulation drives sophisticated depositors, unsubsidized borrowers, and other bank stakeholders to book at least some of their business elsewhere: either abroad or in informal or differently regulated domestic markets. Such regulatory arbitrage limits 
the extent to which politicians can promote a distribution of regulatory burdens that arbitrarily narrows opportunities for important sectors of a national economy to accumulate and manage their wealth.

The normative goal of financial reform should be to induce nondiscriminatory and efficient patterns of regulation and supervision. Regulators should be made accountable not just for producing a stable financial economy, but for providing this stability fairly and at minimum long-run cost to society. In practice, this means establishing contractual incentives that would lead authorities to follow market-mimicking standards of supervisory performance. In the absence of explicit or implicit government guarantees, markets would insist that any bank that experiences a spate of opportunity-cost losses do one or more of three things: shrink, raise more equity capital, or pay higher interest rates for its debt. The public policy problem is to design employment contracts that would make it in supervisors' self-interest to invoke "market-mimicking" disciplines when and as a country's important institutions weaken.

Although officials understand that strengthening bank supervision is part of crisis resolution, they seem reluctant to identify the behavioral norms and incentive structures that made a crisis country's supervision weak in the first place or to recommend publicservice contracting and reporting reforms that would be strong enough to make tougher supervision serve an incentive-conflicted regulator's self-interest.

For any regime, the size of tolerable deviations from a fair and efficient distribution of net regulatory burdens increases with the opportunity costs its citizens face in engaging in capital flight. In turn, the benefits and costs of capital flight evolve with information technology, the volatility of the real economy, and the fluidity of the political environment. The information revolution that is underway in finance today makes it short-sighted and inequitable to adopt credit-allocation schemes that inexorably eat away at the capital of a country's banks and that require taxpayers to subsidize weak banks and uneconomic patterns of real investment. Credit-rating agencies and the Basel Committee on Banking Supervision would be well-advised to abandon sampling procedures that set aside the costs of adverse tail events and models that presume that asset risks are relatively stationary over time. They should focus also on finding ways both to bond the scrupulousness with which staff members perform their supervisory duties and to enlist 
forward-looking betting and derivatives markets to help them track the changing odds of defaults in individual countries and industries (Kane, 2003). 


\section{REFERENCES}

Barth, James R., Gerard Caprio, and Ross Levine, 2006. Rethinking Bank Regulation: Till Angels Govern, New York: Cambridge University Press.

Baumol, William, John C. Panzar, and Robert D. Willig, 1986. "On the Theory of Contestable Markets," in C. Frank Matthewson and Joseph E. Stiglitz (eds.), New Developments in the Theory of Industrial Structure. Cambridge, MA: MIT Press, pp. 339-365.

Caprio, Gerard, and Daniela Klingebiel, 1996. "Bank Insolvency: Bad Luck, Bad Policy, or Bad Banking," Annual Conference on Development Economics, Washington: The World Bank, pp. 79-104.

Dermine, Jean, 2003. “European Banking: Past, Present, and Future.," in V. Gaspar, P. Hartmann, and O. Sleijpen (eds.), The Transformation of the European Financial System, Frankfurt: European Central Bank, pp. 31-95.

Garcia, Gillian, and Maria Nieto, 2006. "Banking Crisis Management in the European Union: Multiple Regulators and Resolution Authorities," Journal of Banking Regulation, 6, 215-219.

Herring, Richard, and Til Schuermann, 2006. "Capital Regulation for Position Risk in Banks, Securities Firms and Insurance Companies," in Hal Scott (ed.), Capital Adequacy: Law, Regulation, and Implementation. Oxford: Oxford University Press.

Honohan, Patrick, and Daniela Klingebiel, 2003. "The Fiscal Cost Implications of an Accommodating Approach to Banking Crises," Journal of Banking and Finance, 27, 1539-1560.

Kane, Edward J., 1977. "Good Intentions and Unintended Evil: The Case Against Selective Credit Allocation," Journal of Money, Credit, and Banking, 9, 55-69. , 1981. "Accelerating Inflation, Technological Innovation and the Decreasing Effectiveness of Banking Regulation," Journal of Finance, 36, 355367. 1988. "Interaction of Financial and Regulatory Innovation," American Economic Review, 78, 328-334. 
, 1989. "Changing Incentives Facing Financial-Services Regulators,"

Journal of Financial Services Research, 2, 263-272. , 1998. “Capital Movements, Asset Values, and Banking Policy in

Globalized Markets," in Seongtae, Lee (ed.), The Implications of Globalization of World Financial Markets, Seoul: Bank of Korea, 278-298.

, 2003. "What Kind of Multinational Arrangements Might Best Enhance

World Welfare?,” Pacific Basin Finance Journal, 11, 413-428.

Krugman, Paul, 1979. “A Model of Balance-of-Payments Crises," Journal of Money, Credit, and Banking, 11(August), pp. 311-325.

Portes, Richard, 2008. "Ratings Agency Reform," posted on www.voxeu.org, January 12. Schüler, Martin., 2003. How do Banking Supervisors Deal with Europe-wide Systemic Risk?, Discussion Paper No. 03-03, Centre for European Economic Research. Shadow Financial Regulatory Committee, 2008. Statement No. 255, Statement on Facilitating Mortgage Renegotiations: The Policy Issues, Chicago: February 11. Wilson, J.A.G., 1986. Banking Policy and Structure: A Comparative Analysis. New York University Press, New York.

\footnotetext{
* This essay extends and refocuses analysis first presented in Kane (1998). For helpful comments, the author wishes to thank Gerard Caprio and John Wilson.
} 